\title{
Situs inversus totalis, oesophageal atresia and tracheo-oesophageal fistula
}

\author{
Ramnik V Patel, ${ }^{1,2}$ Bharat More, ${ }^{3}$ C K Sinha, ${ }^{3}$ Shailinder Singh ${ }^{3}$
}

${ }^{1}$ Department of Paediatric Urology, University College London Hospitals NHS Foundation Trust, London, UK ${ }^{2}$ Department of Paediatric Urology, Great Ormond Street Children Hospital NHS Trust, London, UK

${ }^{3}$ Department of Paed Surgery, QMC, Nottingham, UK

\section{Correspondence to} Ramnik V Patel, ramnik@ doctors.org.uk
To cite: Patel RV, More $B$, Sinha CK, et al. BMJ Case Rep Published online: [please include Day Month Year] doi:10.1136/bcr-2013009955

\section{DESCRIPTION}

A term baby girl had respiratory distress on first feed. She had cardiac impulse and heart sounds on the right side. Liver was palpable below the left costal margin with liver dullness on the left side. An orogastric tube got arrested at $10 \mathrm{~cm}$. Chest $\mathrm{x}$-ray showed the arrest of a replogal tube with its tip at T4 in keeping with oesophageal atresia (OA) and dextrocardia (figure 1A). X-ray abdomen demonstrated gas in the gastric bubble on the right side with liver on the left side suggesting situs inversus totalis (SIT) and bowel loops indicating a distal tracheo-oesophageal fistula (TOF) (figure 1B). ECG confirmed dextrocardia with right-sided aortic arch and small atrial septal defect. She underwent left-sided extrapleural posterolateral thoracotomy, division of TOF and primary repair of OA uneventfully. She is asymptomatic and thriving well at 6 year follow-up.

$\mathrm{OA}$ with TOF and situs inversus of the thoracic and abdominal organs is a very rare combination of congenital anomalies to find in the same patient. ${ }^{12}$ More than $50 \%$ of infants with OA have associated anomalies. When a patient is noted to have congenital heart disease as part of situs anomalies including SIT, or if an atypical position of organs is noted at imaging evaluation, we recommend the patient to undergo chest radiography, abdominal ultrasonography, upper gastrointestinal study and abdominal $\mathrm{CT}^{3}$

\section{Learning points}

Situs inversus totalis (SIT) is a rare anomaly and requires to screen for other anomalies.

- The presence of SIT causes difficulty in the repair of oesophageal atresia with tracheo-oesophageal fistula (OA/TOF).

- SIT with OA/TOF dictates left-sided operative approach.

Contributors All authors have actively contributed in the management of this patient and collection, analysis and interpretation of data and preparation, appraisal and finalisation of this manuscript of this article.

Competing interests None.

Patient consent Obtained.

Provenance and peer review Not commissioned; externally peer reviewed.

\section{REFERENCES}

1 Shenoy VG, Jawale SA, Oak SN, et al. Esophageal atresia with distal tracheoesophageal fistula associated with situs inversus. Pediatr Surg Int 2001;17:538-9.

2 Luo CC, Lin JN, Lien R, et al. A new variant of esophageal atresia with distal tracheo-antral fistula associated with congenital intrathoracic stomach and situs inversus. J Pediatr Surg 2003;38: E25-7.

3 Lee SE, Kim HY, Jung SE, et al. Situs anomalies and gastrointestinal abnormalities. J Pediatr Surg 2006;41:1237-42.

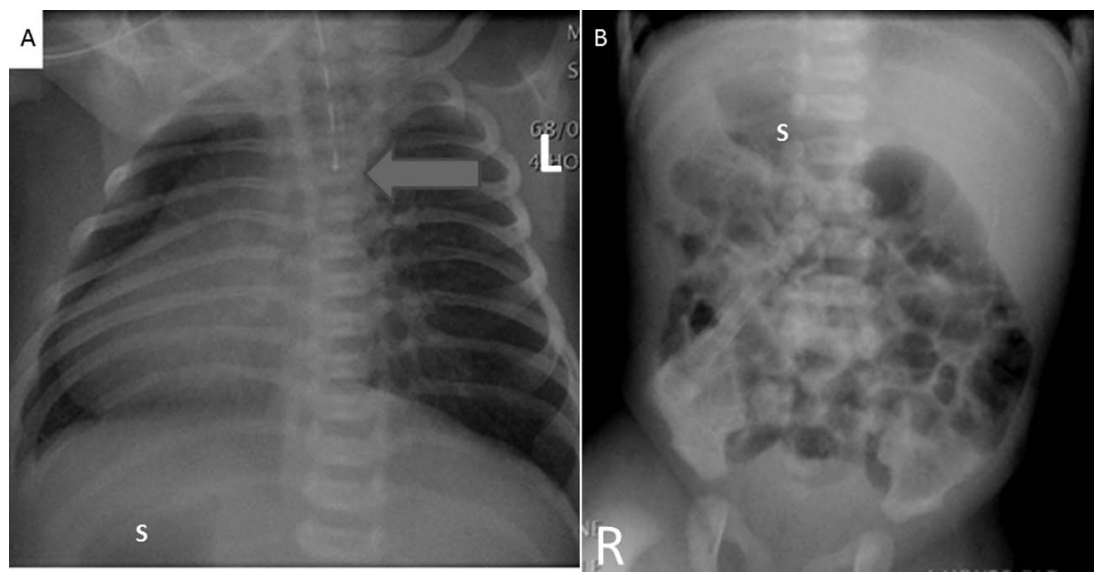

Figure 1 ( $A$ and $B$ ) Chest and abdominal radiographs. Note the arrest of the replogle tube at the C4 level (arrow head) and the stomach bubble on the right $(S)$ and liver shadow on the left side of the abdomen. 


\section{Images in...}

Copyright 2013 BMJ Publishing Group. All rights reserved. For permission to reuse any of this content visit http://group.bmj.com/group/rights-licensing/permissions.

BMJ Case Report Fellows may re-use this article for personal use and teaching without any further permission.

Become a Fellow of BMJ Case Reports today and you can:

- Submit as many cases as you like

- Enjoy fast sympathetic peer review and rapid publication of accepted articles

- Access all the published articles

- Re-use any of the published material for personal use and teaching without further permission

For information on Institutional Fellowships contact consortiasales@bmjgroup.com

Visit casereports.bmj.com for more articles like this and to become a Fellow 